\title{
Aortopulmonary window due to transcatheter pulmonary valve implantation after arterial switch operation
}

\author{
María-Teresa González-López ${ }^{\text {* }}$, Juan-Miguel GilJaurena', José-Luis Zunzunegui-Martínez², \\ Reyes álvarez-García-Rovés ${ }^{2}$ Constancio Medrano-López ${ }^{2}$, Ramón Pérez-Caballero-Martínez' \\ Ana-María Pita-Fernández \\ From World Society of Cardiothoracic Surgeons 25th Anniversary Congress, Edinburgh \\ Edinburgh, UK. 19-22 September 2015
}

\section{Background/Introduction}

Right-sided lesions occur in 5-25\% of patients after arterial switch operation (ASO) and percutaneous or surgical treatments are available (although they are not complication-free).

\section{Aims/Objectives}

We present the first reported case of iatrogenic aortopulmonary window (APW) due to transcatheter pulmonary valve implantation after ASO and the surgical strategy for repair.

\section{Method}

A 12-year old boy (d-transposition of the great arteries and ASO (LeCompte maneuver) in the neonatal period) was referred for transcatheter pulmonary valve implantation due to pulmonary regurgitation. A 22-mm stentmounted valved bovine jugular vein graft (Melody valve, Medtronic, Minneapolis) was implanted, but the patient became hemodynamically unstable (pulmonary-tosystemic ratio 1.96). Transesophageal echocardiography (TEE) showed a traumatic APW in the uppermost portion of the ascending aorta. Haemodynamic stability was achieved following closure using a 10- $\mathrm{mm}$ AmplatzerMuscular-VSD-Occluder but he remained symptomatic in the subsequent weeks. TEE showed residual left-toright shunt in the proximal margin and a covered stent was implanted on the left pulmonary artery (LPA) to deal with the residual shunt, but the Amplatzer was

${ }^{1}$ Paediatric Cardiac Surgery Department, Gregorio Marañón Hospital, Madrid, Spain

Full list of author information is available at the end of the article dislocated. He was referred for emergent surgery. He was cooled to $18^{\circ} \mathrm{C}$ and ventricular fibrillation was achieved. Carbon dioxide field flooding was employed throughout. The circulation was arrested and the right PA was incised and extended toward the LPA. Both percutaneous devices were removed and the APW was closed (Gore-Tex patch). The PA and branches were reconstructed (bypass time 150 and arrest time 23 minutes). TEE showed no residual shunts.

\section{Results}

He had an uneventful recovery and was discharged on 10th postoperative day.

\section{Discussion/Conclusion}

The adherences between the aorta and PA on performing the LeCompte maneuver and the protrusion of the stentmounted valve into the PA bifurcation may result in an APW. Care should be taken in avoiding Melody valve in patients with ASO and surgical option such as valved conduit is advised when significant pulmonary regurgitation is developed.

\section{Consent}

Written informed consent was obtained from the patient for publication of this abstract and any accompanying images. A copy of the written consent is available for review by the Editor of this journal.

\footnotetext{
Authors' details

${ }^{1}$ Paediatric Cardiac Surgery Department, Gregorio Marañón Hospital, Madrid, Spain. ${ }^{2}$ Paediatric Cardiology Department, Gregorio Marañón Hospital, Madrid, Spain.
} 
Submit your next manuscript to BioMed Central and take full advantage of:

- Convenient online submission

- Thorough peer review

- No space constraints or color figure charges

- Immediate publication on acceptance

- Inclusion in PubMed, CAS, Scopus and Google Scholar

- Research which is freely available for redistribution

Submit your manuscript at www.biomedcentral.com/submit 